\title{
Ophrys apifera Huds. (Orchidaceae), a new orchid species to the flora of Poland
}

\author{
Barbara Osiadacz $^{1 *}$ \& Mirosław Kręciała ${ }^{2}$
}

${ }^{1}$ Department of Entomology and Environmental Protection, Poznań University of Life Sciences, Dąbrowskiego 159, 60-594 Poznań, Poland

${ }^{2}$ The Upper Silesian Nature Society, Św. Huberta 35, 40-543 Katowice, Poland

* corresponding author (e-mail: osiadacz@up.poznan.pl)

\begin{abstract}
The paper provides data on the first locality of Ophrys apifera Huds. s. str. in Poland. Information about its geographical distribution and ecological features is given. A newly discovered population, found in a worked-out dolomite quarry near Imielin (Silesian Upland), is described and illustrated, as also, O. apifera is compared with O. insectifera L.
\end{abstract}

Key words: Orchidaceae, Ophrys apifera, orchid species, distribution, Poland

\section{Introduction}

The genus Ophrys L. is a monophyletic group (Soliva et al. 2001), placed in the family Orchidaeceae Juss., subfamily Orchidoideae Lindl., tribe Orchideae Verm., subtribe Orchidinae Verm. (Dressler 1993). The taxonomy of Ophrys was discussed by Devey et al. 2008 and Soliva et al. 2001. This genus comprises from 20 to 200 species dependent on a systematic approach (Nelson 1962; Delforge 2005).

Hitherto, in Poland only the occurrence of one species of this genus was recorded $-O$. insectifera $\mathrm{L}$. (Mirek et al. 2002) - in the small number of localities in southern part of the country, situated beyond the compact range of the species (Kaźmierczakowa \& Zarzycki 2001; Zając \& Zając 2001). In the summer of 2010, during field investigations in a worked-out dolomite quarry near Imielin, the first locality of Ophrys apifera Huds. in Poland was found.

The aim of this study is to document the findings and preliminary description of a previously unknown population and locality. General knowledge about the taxonomy, morphology, biology, distribution and ecology of the species was also presented.

\section{Classification and morphology}

Ophrys apifera Huds belongs to the complex: Ophrys fuciflora, and section: Euophrys Delforge
(2005). The name of genus (from Greek "ophrys", ang. Lash) is most probably connected with ciliated labellum occurring in majority of species of this genus (Piękoś-Mirkowa \& Mirek 2003). The species name is derived from the Latin words: "apis" (=bee) and "fero" (=to carry). According to Soó (1980), the plant grows to $20-50(70 \mathrm{~cm})$ with two ovate tubers. The stem has 1-2 basal leaves, 2-4 rosette leaves and 4-7 leaves growing above. Lanceolate leaves of 6-13 cm and 1.5-2.8 $\mathrm{cm}$ wide. Coloured flowers, in number of 3-10(-17) in long inflorescence. The number and vigorousness of individuals as well as number of flowers in inflorescence are different in various habitats and very changeable year to year, dependent on weather conditions. Sepals of 11-17 mm and 5-9 mm wide, pink or red, ovate-lanceolate. Lateral petals of 2.5-7.0 mm, pink or greenish, hairy, truncate. Wide labellum of 9-14 mm, without spur, profoundly tree-lobed with brown medium marking, at the front part strongly protuberant with bent tip, haired margin and large downward lanceolate or trapezoid $3 \mathrm{~mm}$ appendix with medium tip. "Mirror" encompassing basal field (frequently protruding forward or sideward) brown with white margin. Tubers at the bottom of strongly downward, densely haired lateral lobes. The base of labellum with two yellow basal nodes with dark tips, at the margin marked with two red staminoidal points. The gynostemium with bent connectivum 2-3 mm. Number of chromosomes $2 \mathrm{n}=36$ (Bianco et al. 1987). 


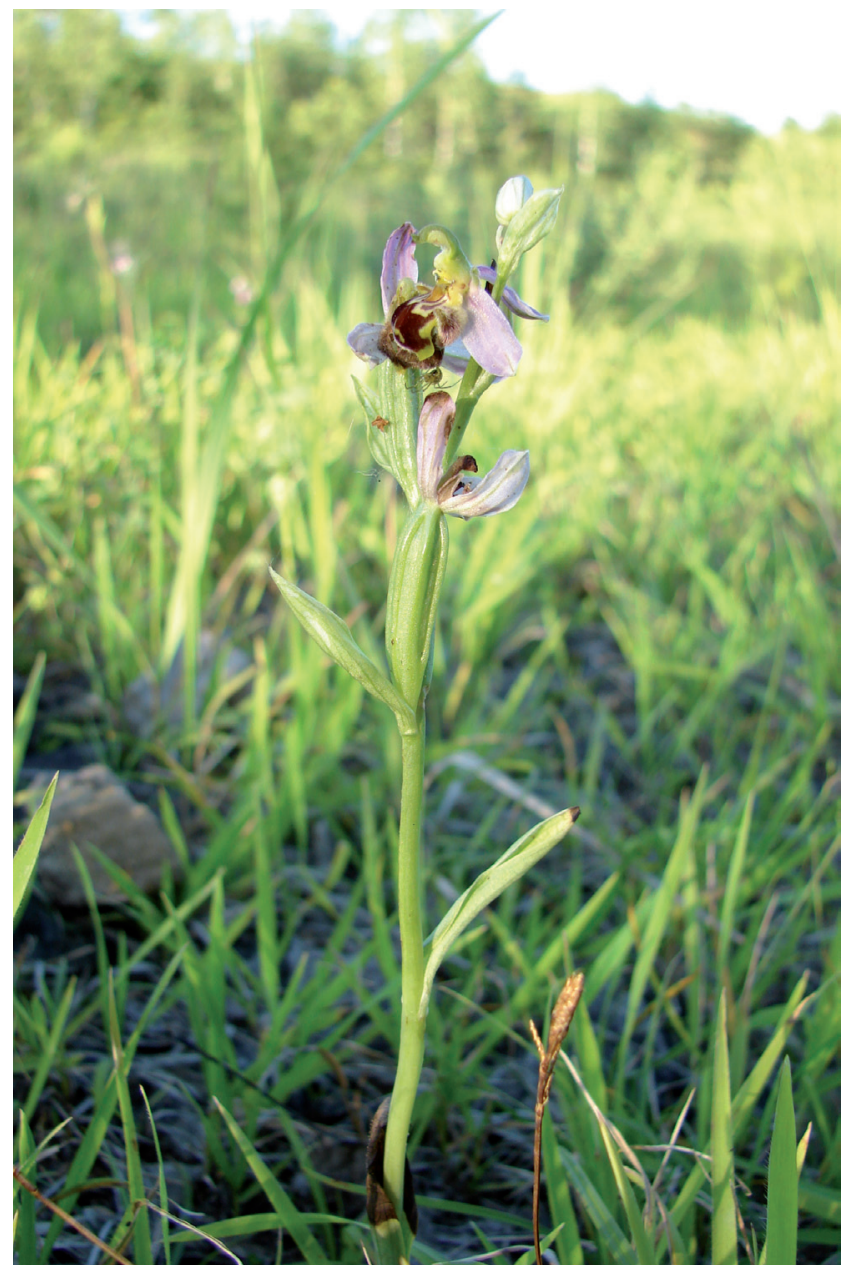

Fig. 1. Ophrys apifera Huds. - locality in the worked-out dolomite quarry near Imielin (29.06.2010, photograph by M. Kręciała)

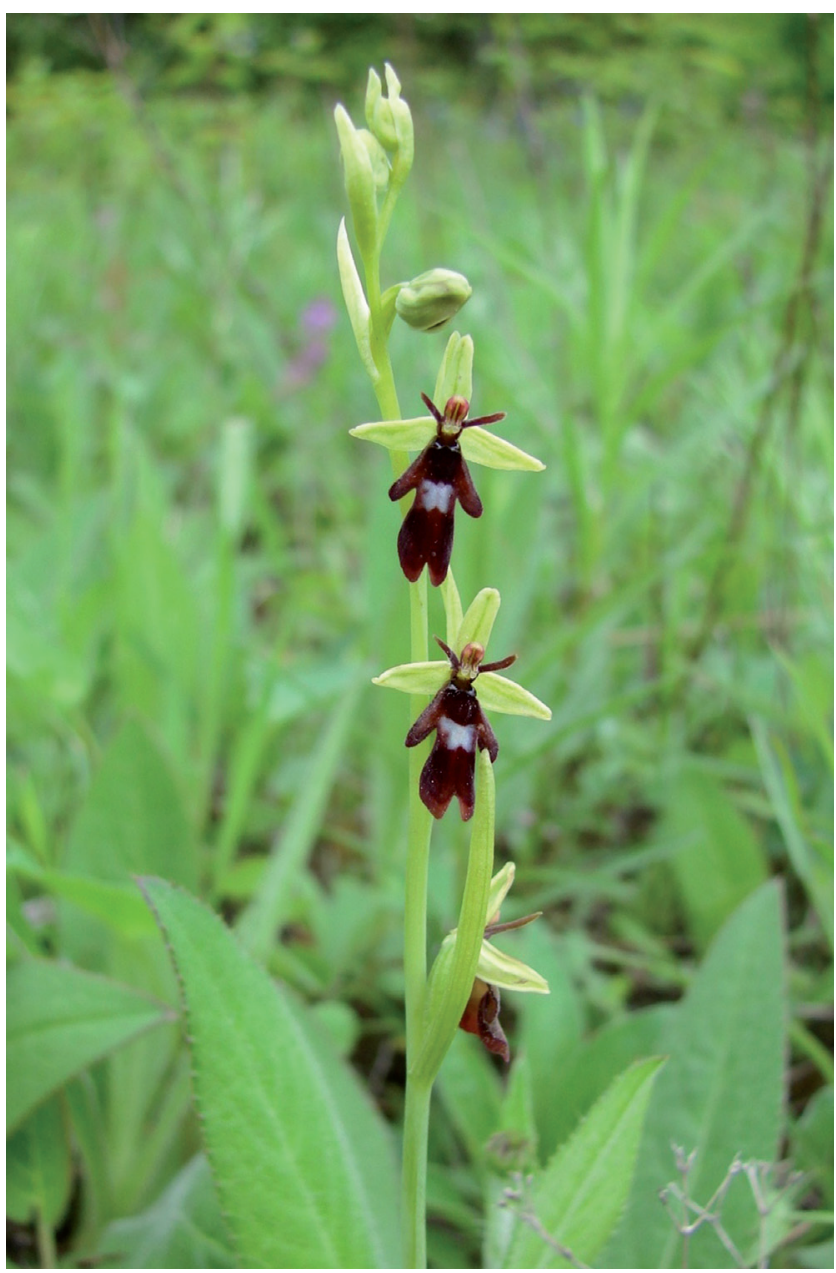

Fig. 2. Ophrys insectifera L. - locality in Kalina Lisiniec (23.05.2008, photograph by M. Kręciała)
Ophrys apifera in contradistinction to $O$. insectifera is characterized by: lip with a tooth-like appendage at the apex, speculum H-shaped or shield- or W-shaped, violet-purple with a pale green margin, sometimes indistinct, anther-connective pointed (Figs. 1-2).

\section{Biology}

Ophrys apifera is perennial and geophyte. Early stages of ontogenesis in this species were studied in the middle of the $19^{\text {th }}$ century (Fabre 1857). Seed germination occurs in March. In the same period, weakly differentiated protocorms with rhizoids appear in soil. First aerial green leaf is formed 2 years after seed germination and the plant starts flowering in the age of 9-11 years (May and June) (Ziegenspeck 1936; Summerhayes 1951). A fruit contains about 10,000 seeds. In favourable seasons, vegetative reproduction may occur, if 2 daughter tuberoids are formed (Lang 1980). In natural conditions O. apifera forms mycorrhiza intensively (Rasmussen 1995).
O. apifera may flower only once in their lifetime (which explains their erratic appearance in large numbers some years and disappearance in others). Biology of pollination of this species is subject of many longterm studies. Since flowers of $O$. apifera are similar to females of Aculeata of the Andrena genus (Szafer 1969), it was believed that zoogamy occurs likewise in other species of the Ophrys genus. Kullenberg (1961) observed, how various male insects of the genus $E u$ cera and Tetralonia were attracted to the flower and attempted copulation. Darwin (1877) was the first to report that $O$. apifera is self-pollinating. Claessens \& Kleynen (2002) showed that insects do not play any role in the process of pollination - the species is an almost obligate autogam. According to Kullenberg \& Bergström (2008), pollination in O. apifera can be realized in two ways - with participation of males of Eucera or autogamically.

Occasional hybrids with other Ophrys species, among others, hybrid with $O$. insectifera $-O$. × pietzschii Kümpel ex F. J. Rumsey \& H. J. Crouch - known, 


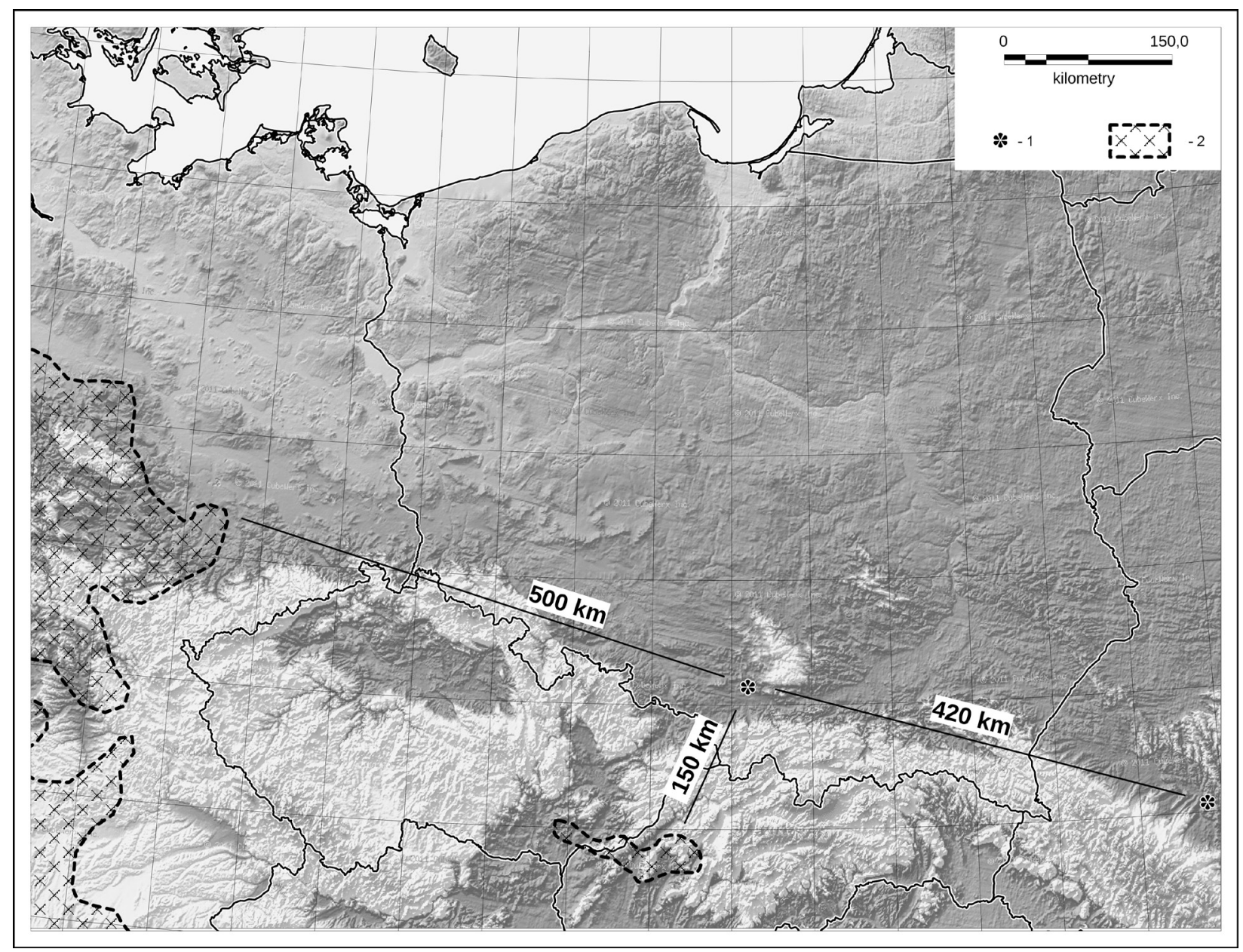

Fig. 3. Distribution of Ophrys apifera Huds. in Central Europe

Explanations: 1 - localities of Ophrys apifera Huds. in Poland and Ukraine (Danylyk \& Borsukevych 2011), 2 - range of Ophrys apifera Huds. in Germany (Kretzschmar 2014), Czech and Slovakia (Čeřovský et al. 1999)

e.g., from natural localities in England, France and Germany (Willis 1980; Rumsey et al. 2012), may be due to insect visitors removing excess pollen from alreadyfertilized flowers (Turner Ettlinger 1998). The species reproduces by seeds and vegetatively (Lang 1980).

\section{General distribution and habitat conditions}

It is one of the most successful Ophrys species as proves its large distribution area (Soliva et al. 2001). This species is an Euromediterranean geoelement. It is comparatively widely distributed in Europe - in western part of Europe with oceanic climate, it ranges to the north (south of the Scandinavian Peninsula and England) (Buttler 2000; Vakhrameeva et al. 2008; Gardiner \& Vaughan 2009; Turner Ettlinger 1998). Its areal reaches east to the Caucasus Mts. and south to North Africa. Hitherto, localities situated nearest the borders of Poland were found in the Czech Republic, Slovakia (ca $150 \mathrm{~km}$ away) and Germany (ca $500 \mathrm{~km}$ ) (Fig. 3). This species also occurs in Ukraine - in the Crimean peninsula and Ivano-Frankivsk Region (Danylyk \& Borsukevych described this locality in 2011).

It inhabits areas from light to shady, from dry to moist meadows or open forests, up to $1800 \mathrm{~m}$ alt. (Vakhrameeva et al. 2008). High concentration of flavonoids in the sepals and labellum, possibly indicates the necessity for stronger UV-B protection. The above feature could be attributed to the adaptation of $O$. apifera to higher altitudes (up to $1800 \mathrm{~m}$ a. s. 1.) compared with the other Ophrys species (Karioti et al. 2008).

This orchid is more commonly recorded on soils with a high pH (7) (Gardiner \& Vaughan 2009). It is a pioneer species and among the first to appear on disturbed sites (Wells \& Cox 1991). In recent years, information about the appearance of $O$. apifera in secondary and urban locations in Western Europe (such as: brown coal opencast mines areas, former mine waste dumps, inactive landfills of debris, worked-out quarries, and also urban green spaces - lawns, cemeteries, parks and gardens) became more common (Hammel 2008; Heinrich \& Dietrich 2008). 
The species grows usually in small groups of 1-3 (max 5) individuals, contrary to $O$. insectifera, which populations can be estimated at several dozens of individuals (Kaźmierczakowa \& Zarzycki 2001; Vakhrameeva et al. 2008).

\section{Material and methods}

As a part of our field studies of aphidofauna of semi-natural dry grasslands in Poland, conducted in May-August 2010, we visited several locations in the area of Imielin and Jaworzno and discovered population of $O$. apifera in one of them. Next, we conducted some other field investigations in the surrounding area, but we found no other populations of $O$. apifera. Plants were photographed and their positions noted and mapped.

The herbal material, i.e., a flower, was delivered to the Herbarium of Department of Plant Systematics of Silesian University. The detailed geographical coordinates of the locality were delivered to the Editorial Board of "Biodiversity: Research and Conservation" and are stored in the database of Upper Silesian Nature Heritage Center.

\section{Results}

In the summer of 2010, the first locality of Ophrys apifera Huds. in Poland has been found (ATPOL: DF54) during the field investigations in the worked-out dolomite quarry near Imielin. According to the physicalgeographical division by Kondracki (2009), this area is included in the macroregion Silesian Upland (341.1) and mesoregion Jaworznickie Hills (341.14).

A single flowering individual of $O$. apifera (Fig. 1) was found in the direct vicinity of the path along the edge of the quarry. The inflorescence contained 4 flowers: 1 well-developed, two faded flowers and 1 flower bud. Unfortunately, despite further investigations, no other individuals were noted. The locality has been constantly monitored, however, no $O$. apifera individuals were found during the research conducted in 2011, 2012 and 2013.

The locality of $O$. apifera is located on the southfacing slope built by the dolomites of Medium Triassic period at $290 \mathrm{~m}$ a. s. 1. It is covered by calcareous grassland in the phase of succession of overgrowing an exploitation hollow on rendzina (Fig. 4). The community is mainly built by: Brachypodium pinnatum, Anthyllis vulneraria and Ononis spinosa. These taxa are accompanied by not numerous individuals of: Leontodon hispidus, Lotus corniculatus, Picris hieracioides, Sanguisorba minor and Silene otitis, and single individuals of: Artemisia campestris, Briza media, Calamagrostis epigejos, Campanula glomerata, Carlina acaulis, C. vulgaris, Centaurea scabiosa, C. stoebe, Coronilla varia, Echium vulgare, Galium mollugo, Gypsophila fastigiata, Hieracium piloselloides, Hypericum preforatum, Linum catarthicum, Medicago $\times$ varia, Peucedanum oreoselinum, Scabiosa ochroleuca, Thesium linophyllum and Thymus pulegioides. Intensive encroachment of Betula pendula and Pinus sylvestris, as well as seedlings of Aesculum hippocastanum, Fraxinus excelsior and Quercus rubra were observed.

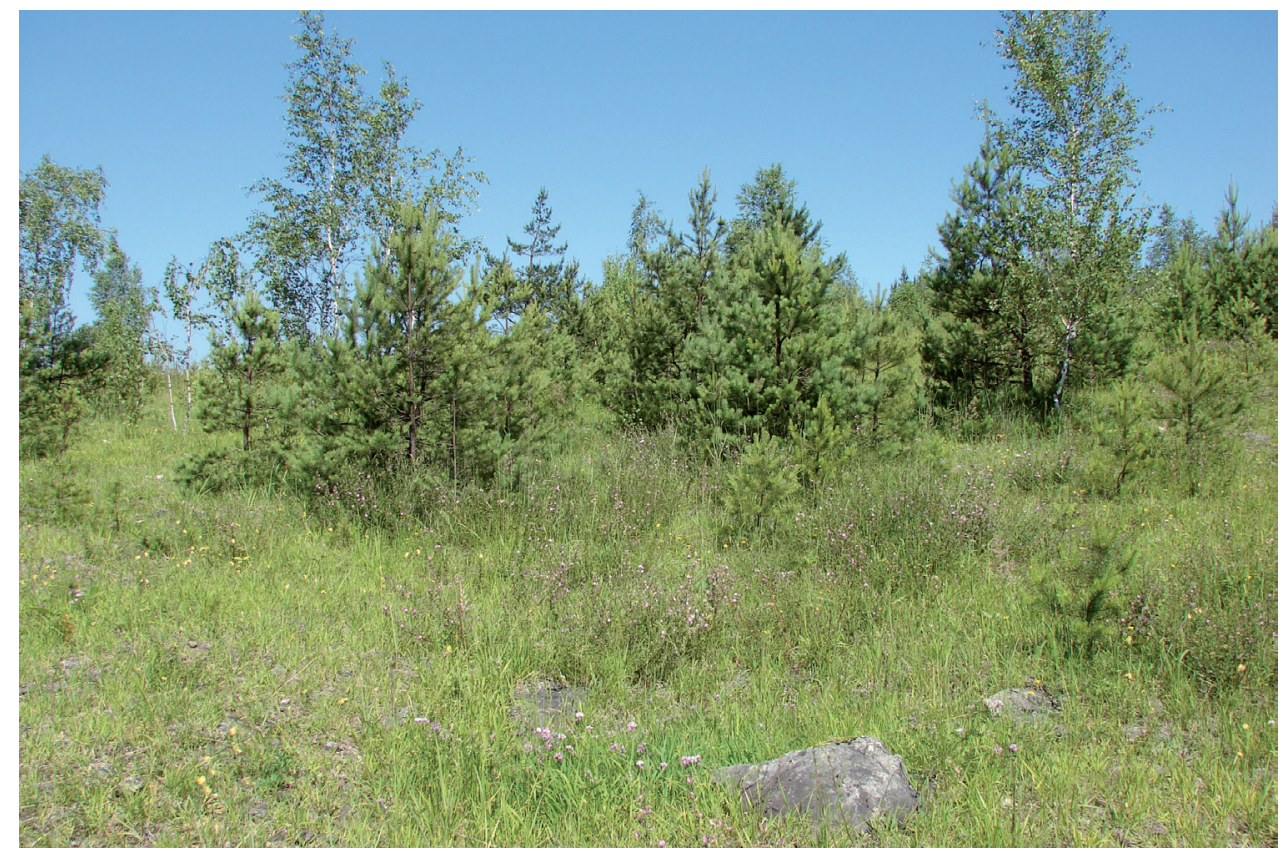

Fig. 4. Locality of Ophrys apifera Huds - the worked-out quarry near Imielin (29.06.2010, photograph by M. Kręciała) 


\section{Discussion}

The first locality of $O$. apifera in Poland is located beyond the compact range of this species. It is probably the most northeastern locality in Central Europe. Also, in 2010, O. apifera has been observed in Ukraine, for the first time outside the only sites so far known, grouped in the Crimean peninsula (Danylyk \& Borsukevych 2011). Such information, as well as the appearance of this species in the secondary and urban locations in Western Europe (Heinrich \& Dietrich 2008), may also indicate the increase of its range.

A characteristic feature of the Ophrys species, essential for their spread, is a production of the large number of small-sized seeds (Devey et al. 2008). The increase in range of Ophrys apifera and other species of this genus can be determined by climate changes (Houghton et al. 2001) in last decades, which might be reflected by, among others, strong winds. Based on the data from the meteorological station in Sosnowiec, it could be suspected that this species arrived to Poland from the south through the Moravian Gate. Only genetic studies comparing individuals occurring in Poland with the Czech population of this species may confirm this hypothesis.

$O$. apifera is an autogamous species and therefore it can become naturalized in Poland. However, it can grow only in specific habitats, similar to those occurring within its compact range or analogous for newly opened postglacial areas (Devey et al. 2008). Also, it can occur in some anthropogenic locations, like in Western Europe. On the other hand, autogamy may cause threat to this species through limitation of genetic diversity of its populations or displacement by congeneric hybrids. The genus Ophrys is a relatively young group, in which genetic and behavioral barriers did not fully developed. It should be also noted that many species of Ophrys prefer 'man-made' (anthropogenic) and 'man-maintained' (anthropostatic) biotopes (Devey et al. 2008). In Poland, $O$. apifera is reported from a worked-out quarry - manmade environment, which may be treated as a freshly uncovered post-glacial site, while $O$. insectifera occurs in xerothermic grasslands - anthropostatic environment, which was formed or is maintained owing to man for relatively long time.
Based on the analysis of distribution of species from the genus Ophrys in the territory of Poland, it can be concluded that individual populations of $O$. insectifera are well-isolated and the chance of hybridization with $O$. apifera (Willis 1980; Vakhrameeva et al. 2008; Rumsey et al. 2012) is currently insignificant. Under these circumstances, it is necessary to monitor both a new locality of $O$. apifera and known localities of $O$. insectifera, as well to search for further localities of these species.

The Ophrys apifera has been included in the CITES Convention (Appendix II) as an endangered species which is - or may become - the object of trade. In the area of Carpathians Mts, the species is considered as threatened (Category EN - endangered). It is also under legal protection in the Czech Republic, Slovakia and Hungary (Witkowski et al. 2003). Moreover, it is mentioned in the Red Books of Czech Republic and Slovakia (category $\mathrm{CR}$ - critically endangered) (Čeřovský et al. 1999) and the Red Book of Ukraine - category endangered (Didukh 2009).

The described site of $O$. apifera is situated in the unprotected area. Therefore, we suggest that the species category of threat should be CR - critically endangered. Thus, it seems sensible to include it in the List of the protected plants in Poland. Moreover, due to the occurrence of well-developed dry calcareous grasslands with rare and protected plants in the studied locality, it is suggested to recognize the whole area as a protectionlandscape area. Also, it seems necessary to use conservation management practices consisting in removal of pines and birches (such treatment was conducted in the summer of 2012 and 2013). As study by Gardiner \& Vaughan (2009) shows, O. apifera responds well to the disturbance of the soil. Their observations suggests that the combination of scrub clearance followed up by a small-scale soil disturbance enhanced the establishment of this orchid in the calcareous grassland.

Acknowledgments. Authors wish to thank dr Leszek Bernacki for confirmation of proper identification of the found individual, dr Adam Rostański for valuable remarks and comments during preparation of this paper and dr Beata Babczyńska-Sendek for help and precious remarks concerning the location of examined localities.

\section{References}

Bianco P., Medagli P., D’Emerico S. \& Ruggiero L. 1987. Numeri cromosomici per la Flora Italiana. Inf. Bot. Ital. 138: 322-332.

ButtLer K. P. 1991. Field guide to orchids of Britain and Europe. The species and subspecies growing wild in Europe, the Near East and North Africa with drawings by the author. 280 pp. The Crowood Press, Swindon.
Čeřovský J., Feráková V., Holub J., Maglocký Š. \& ProCHÁzKA F. 1999. Červená kniha ohrožených a vzácných druhů rostlin a živočichů ČR a SR. Vol. 5. Vyšší rostliny. 453 pp. Príoda a s., Bratislava.

Claessens J. \& Kleynen J. 2002. Investigations on the autogamy in Ophrys apifera Hudson. Jber. naturwiss. Ver. Wuppertal. 55: 62-77. 
Danylyk I. M. \& Borsukevych L. M. 2011. A new find of Ophrys apifera Huds. (Orchidaceae) in Ukraine. Ukr. Botan. Journ. 68(1): 58-63.

DARWIN C. 1877. Various Contrivances by Which Orchids Are Fertilized by Insects. 365 pp. John Murray, London.

Delforge P. 2005. Guide des Orchidées d'Europe, d'Afrique du Nord et du Proche-Orient. 640 pp. Delachaux et Niestlé, Paris.

Devey D. S., Bateman R. M., Fay M. F. \& Hawkins J. S. 2008. Friends or Relatives? Phylogenetics and Species Delimitation in the Controversial European Orchid Genus Ophrys. Ann. Bot. 101: 385-402. doi:10.1093/ aob/mcm299.

DidukH Y. P. (ed.) 2009. Červona knyga Ukrainy, Roslynnyi svit. 912 pp. Globalkonsaltyng, Kyiv.

Dressler R. L. 1993. Phylogeny and Classification of the Orchid Family. 321 pp. Dioscorides Press, Portland.

FABRE J. H. 1857. De la germination des Ophrydées et de la nature de leurs tubercules. Ann. Sci. Nat. Bot. Biol. 5: 163-186.

Gardiner T. \& Vaughan A. 2009. Scrub clearance and soil disturbance increases bee orchid Ophrys apifera frequency in calcareous grassland at Norton Heath roadside verge, Essex, England. Conserv. Evid. 6: 39-41.

HeinRich W. \& Dietrich H. 2008. Heimische orchideen in urbanen biotopen. Feddes repert. 119(5-6): 388-432.

Hammel S. 2008. Ophrys apifera Huds. in Scherrasen des Cynosurion Tx. 47-Verbandes. J. Eur. Orchid. 40: 3-23.

Houghton J. T., Ding Y., Griggs D. J., Noguer M., van der Linden P. J., Dai X., Maskell K. \& Johnson C. A. (eds.). 2001. Climate Change 2001: The Scientific Basis. 892 pp. Cambridge University Press, Cambridge-New York.

Karioti A., Kitsaki C. K., Zygouraki S., Ziobora M., Djeddi S., Skaltsa H., Liakopoulos G. 2008. Occurence of flavonoids in Ophrys (Orchidaceae) flower parts. Flora 203(7): 602-609. doi:10.1016/j.flora.2007.09.009.

KAŹMIERCZAKOWA R. \& ZARZYCKI K. 2001. Ophrys insectifera L. - dwulistnik muszy. In: R. Kaźmierczakowa \& K. ZARZYCKI (eds.). 2001. Polska Czerwona Księga Roślin. Paprotniki i rośliny kwiatowe, wyd. 2, pp. 572574. PAN, Instytut Botaniki im. W. Szafera, Instytut Ochrony Przyrody, Kraków.

Kondracki J. 2009. Geografia regionalna Polski. 444 pp. PWN, Warszawa.

Kretzschmar H. 2014. Ophrys apifera Huds. In: H. KretzSCHMAR. Orchideen in Deutschland. Arbeitskreise Heimische Orchideen. http://orchideen-kartierung.de/ GERMANY/OPAPIF (WWW document). Accessed 14 February 2014.

Kullenberg B. 1961. Studies in Ophrys pollination. Zool. Bidr. Upps. 34: 1-340.

Kullenberg B. \& Bergström G. 2008. Hymenoptera aculeata males as pollinators of Ophrys orchids. Zool. Scripta. 5(1-4): 13-23.

LANG D. 1980. Orchid of Britain. A field Guide. 213 pp. Oxford University Press, Oxford.
Mirek Z., Pięroś-Mirkowa H., ZająC A. \& Zając M. 2002. Flowering plants and pteridophytes of Poland. A checklist. In: Z. Mirek (ed.). Biodiversity of Poland, 1, 442 pp. W. Szafer Institute of Botany, Polish Academy of Sciences, Kraków.

Nelson E. 1962. Gestaltwandel und Artbildung Erörtert am Beispiel der Orchidaceen Europas und der Mittelmeerländer. 249 pp. Fischer, Chernex-Montreux.

Piękoś-Mirkowa H. \& Mirek Z. 2003. Flora Polski. Atlas roślin chronionych. 584 pp. MULTICO Oficyna Wydawnicza, Warszawa.

RAsmussen H. N. 1995. Terrestrial orchids from seed to mycotrophic plant. 445 pp. Cambridge University Press, New York.

Rumsey F. J., Crouch H. J. \& Tosh J. 2012. Review of Ophrys apifera $\times O$. insectifera (beefly orchid) in the British Isles, with validation of the hybrid name Ophrys xpietzschii. New Journal of Botany 2(2): 100-109. doi:10.1179/2042349712Y.0000000011

Soliva M., Kocyan A. \& Widmer A. 2001. Molecular phylogenetics of the sexually deceptive orchid genus Ophrys (Orchidaceae) based on nuclear and chloroplast DNA sequences. Mol. Phylogenet. Evol. 20(1): 78-88. doi:10.1006/mpev.2001.0953.

Soó R. 1980. Ophrys L. In: T. G. Tutin, V. H. Heywood, N. A. Burges, D. M. Moore, D. H. Valentine, S. M. Walters \& D. A. Webi (eds.). Flora Europaea, Vol. 5, pp. 344-349. Cambridge University Press, Cambridge.

Summerhayes V. S. 1951. Wild orchids of Britain. 366 pp. Collins, London.

SzAFER W. 1969. Kwiaty i zwierzęta. Zarys ekologii kwiatów. 387 pp. PWN, Warszawa.

Turner Ettlinger D. M. 1998. A new variety of Ophrys apifera Hudson (Orchidaceae). Watsonia 22: 105-107.

Vakhrameeva M. G., Tatarenko I. V., Varlygina T. I., ToroSYAN G. K. \& ZAGULSKI M. N. 2008. Orchids of Russia and Adjacent Countries (within the borders of the former USSR). 693 pp. A.R.G. Gantner Verlag, Ruggel.

Wells T. C. E \& Cox R. 1991. Demographic and biological studies on Ophrys apifera: some results from a 10 year study. In: T. C. E. Wells \& J. H. Willems (eds.). Population ecology of terrestrial orchids, pp 47-61. SPB Academic Publishing, The Hague.

Willis A. J. 1980. Ophrys apifera Huds. $\times$ O. insectifera L., a natural hybrid in Britain. Watsonia 13: 97-102.

Witkowski Z. J., Król W. \& Solarz W. (eds.). 2003. Carpathian List Of Endangered Species. 64 pp. WWF \& Institute of Nature Conservation, Polish Academy of Sciences, Vienna-Krakow.

ZAJĄC A. \& ZAJĄC M. (eds.). 2001. Distribution Atlas of Vascular Plants in Poland. xii+714 pp. Edited by Laboratory of Computer Chorology, Institute of Botany, Jagiellonian University, Cracow.

ZiegensPeCK H. 1936. Orchidaceae. In: O. Kirchner, E. Loew, C. Schroeter (eds.). Lebensgeschichte der Blütenpflanzen Mitteleuropas Bd. 1, Abt. 4. 840 pp. Verlagsbuchhandlung Eugen Ulmer, Stuttgart. 